\title{
Academic Management of Excellent Engineer Training Program for Specialty of Mechanical Design \& Manufacture Based on CDIO Model
}

\author{
Shao Junpeng \\ College of Mechanical and Power Engineering \\ Harbin University of Science and Technology \\ Harbin, China \\ sjp566@sina.com
}

\author{
Sui Xiulin, Chen Si \\ College of Mechanical and Power Engineering \\ Harbin University of Science and Technology \\ Harbin, China \\ suixiulin@sina.com
}

\begin{abstract}
The academic management problems of "excellent engineers educating and training program" in colleges and universities are discussed, and its characteristics, connotation and appearance are expounded. The current status quo and the main existing problems of academic management from our national colleges and universities are analyzed, and five ways are proposed to strengthen the academic management of "excellent engineers educating and training program ".
\end{abstract}

Keywords-excellent engineer education; training program; academic management; teaching management; reform of higher education

In October 2006, the Ministry of Education launched the pilot reform of higher engineering education. The "excellent engineers educating and training program" has expanded in some national pilot universities and spreads to universities across the country. Exploring innovative training models and management reform has become a major long-term reform measure of higher education in china. How to fully understand the position of academic management, establish the mechanism of, and play the role of academic management in teaching management to improve the level of modern teaching management and the quality of teaching of the excellent engineer personnel training, have become an urgent and important subject in Chinese universities

\section{APPEARANCE OF ACADEMIC MANAGEMENT DURING} THE EXCELLENT ENGINEER PERSONNEL TRAINING

The concept of academic management in teaching management emerged in the mid-1990s [1]. It mainly refers to the management of academic affairs and activities in higher education. Academic management ensures a free space for the spirit of innovation and creativity of teachers and scholars. Because the function of higher education is implemented through the academic affairs and academic activities, the academic management should be a core part of the university management. Mr. Zhu Jiusi once said: "The three parts of higher education management are administration management, academic management and thinking management". They are closely linked with each other and mutually restricted. The connotation of the academic management mainly express in five aspects: (1) The objects of academic management are academic affairs and academic activities in the higher education. (2)A variety of management methods and mechanisms can be used; (3)
The body of academic management is the staff undertook the function of academic management; (4) The academic management not only refers to the management of the academic affairs and activities in universities, but also includes some of the impact and the role played by various outside social organizations, institutions or forces. (5)Academic management is the core of the management of higher education, truly embodying the characteristics and reflecting the essence of the higher education [2].

Academic management includes the academic democratic management and academic administrative management. Academic democratic management is the traditional management model of higher education in the west. In the early, almost all the western universities adopted the academic democratic management, and the teaching affairs in the university are mainly negotiated and decided by the professors. The connotation of the modern academic democratic management mainly has the following aspects. (1)Academic democratic management is a basic right of the front-line teachers, fully highlighting the concept of teachers as the school principal. (2)The jurisdiction areas of the academic democratic management have mainly concentrated on academic affairs, such as academic development planning, the scale of enrollment, curriculum, the arrangement of the teachers' teaching task, research activities and various affairs related to the academic work. (3)The mechanism and the rules and regulations of the academic democratic management are sound, the operational procedures are standard, and the operating system has rules to follow. (4)A clear division between academic democratic management and academic administration management is executed, and there is a good co-operation. The former is responsible for the deliberations and decisions of the major academic affairs, and the latter is responsible for the organization and implementation and the daily management related to the decisions of academic affairs. (5)The main body of academic democratic management is diversified, and has gradually transformed the prerogative of the senior professors into a power enjoyed by the whole school teaching staff, and even students in a certain extent, may have opportunities to participate.

Academic administrative management plays a pivotal role in the modern higher education all over the world, especially in China. The connotation of the modern academic administrative management mainly has the four aspects: (1)The idea that principals govern school and 
teachers govern students has a profound influence, and the principal is a symbol of academic leaders. (2)Academic administrative management system includes all the academic affairs of management activities, and the academic administrative agencies of all levels and professionals are the center of the power for academic management. (3)The decision right of academic management is concentrated in the upper academic administrative department, and middle and lower classes is primarily responsible for the organization and implementation of academic affairs. (4)Academic democratic management plays a role as an adjunct of the academic administrative management, not only in the specific management matters, but also in the influence [3].

Academic management in excellence engineers personnel training mainly express in the three aspects: Firstly, universities and enterprises jointly carried out some thing, such as the research of disciplines structure, professional setting and adjustment, design, revising, implementation and management of professional teaching program, opening of various courses, the formulate and management of teaching content and syllabus. Secondly, playing the advantages of enterprises, schools and enterprises purposefully organize and launch educational research and teaching reform, such as research of advanced educational philosophy and thought, teaching seminars, discussion on personnel training modes, personnel training programs and classroom teaching modes, and reform of teaching methods. Thirdly, develop the study of the standards of teaching quality, and evaluate, monitor and manage the teaching quality together with enterprise, such as the formulation of main teaching links and the teaching quality evaluation system.

\section{PRESENT STATUS AND EXISTING PROBLEMS OF ACADEMIC MANAGEMENT IN UNIVERSITIES IN CHINA}

\section{A. Present status of academic management organization and personnel}

Looking at the internal teaching management of colleges and universities at home and abroad, there are two main power played a decisive role: One is leaders in various management and executive staffs as the main administrative management, namely the power implemented by the party and government departments in colleges and universities. The other is famous professors, scholars and experts in various disciplines as the main academic management, and the power relying on various academic committees [4]. The teaching administrative organizations in current universities have four distinct characteristics: (1)have a statutory jurisdiction area; (2)determine offices based on the hierarchy; (3)perform the administrative management mainly based on files and professionals ${ }^{[4]}$. The current teaching administrative organizations in universities mainly focus on the school, the college and the department, and the power of teaching management is executed through the three teaching administrative organizations to ensure the normal operation of teaching work and the stability of the teaching order; (4)there are not related enterprises and professionals to participate in the management. The quality of the professional involved in teaching administrative management at this stage, such as the academic level and the operational capacity, need have a further improvement. Some teaching management personnel in colleges and universities do not learn the basic theory of education, and do not know the basic rules of education, lacking of the concepts and skills of modern teaching management [5].

\section{B. A serious loss of power for academic management in colleges and universities}

Academic management mainly focus on university teachers, the academic development planning and the important issues in teaching, research and other academic activities are determined using democratic methods and academic discussion. The purpose is to ensure to run a school according to the laws of academic development in colleges and universities. This academic management often tends to be in a dominated position in colleges and universities, so that it is often ignored by school leaders who are the core layer of the administrative power. Experts and professors play a minimal role in the assessment grades except for the occasional consulting, and the opportunities to participate in decision and management of teaching are few. As a carrier of the power for academic management, the school professors committee and the academic committee can not be given full play the functions, and the experts from enterprises can not be put in place to participate in the management. Academic freedom ultimately expressed as academic power is not more fully realized, so teachers can not enjoy the true freedom of teaching, and students are also difficult to have their own independence and freedom of learning. Moreover, various exchange, contention and published of academic thinking are also subject to varying degrees of restrictions. Universities are regard as the home of knowledge, and academic activities are the most basic activities in colleges and universities. If the administrative power is excessively executed, the academic power will be suppressed, and the academic community will lose the vitality [6].

\section{Lack of teachers' right to speak under the current system}

Under the current teaching administrative system, teachers are managed not only by the leaders of college and department, but also by various functional departments. Usually teachers were required to implement the plan in accordance with the requirement of leaders and administrators. Teachers merely are the executors of the teaching work, and they are at a disadvantage in the decision of the teaching management and reform, so that it is difficult to make their voices heard. Teachers' right to speak is limited to the teaching content oriented to student. Under this system, the appeal of the first-line underlying teachers to the teaching administrative departments and faculties leaders are weak, causing the silence is the status of their survival [7]. Because teachers do not have the right to speak facing the authorities, and they are commanded and managed in the long term, there are minimal opportunities for them to participate in teaching management and decision-making, so that teachers 
do not actively participate in the management and decisionmaking of the schools, colleges and the departments, individual teachers are not serious and academic interest is not strong. At the same time, under the current teaching management system, teachers' value is not dependent on teaching value, academic value, social value and cultural value, but depends on the size of its official position. However, the premise accessed to the official position is respected and responsive to the power, not academic achievements, causing the consciousness of official positions is spread and strengthened in colleges and universities, thus people care about politics more than academic, and chase for level and position more than career and learning.

\section{STRENGTHEN THE WAYS OF THE ACADEMIC MANAGEMENT IN EXCELLENCE ENGINEERS PERSONNEL TRAINING}

\section{A. Update the idea of teaching management and strengthen the decision of academic management}

Improving teaching quality and training qualified talent mainly lie in the teaching management in colleges and universities. Traditional teaching management exist the drawbacks that the administrative management is emphasized and the academic management is underestimated, causing the rich connotation of teaching management becomes the sole administrative management, just satisfying with maintenance the normal teaching order and processing the teaching accident. This one-sided understanding and practice should be fundamentally eliminated. Teaching academic management is an important part of teaching management practical activities. The erroneous ideas that "professors or experts running the schools" will weaken the leadership of party should be completely eliminated. At the same time the thought, such as experts are many, opinions is mixed and efficiency making decision is slow, should be completely removed. It is necessary to recognize the seriousness of the harm caused by education policy mistakes. The efficiency making decision of the education is built on the basis of the decision sciences to prevent the serious consequences of the teaching work due to "fast decisionmaking, large deviations".

\section{B. Set up the academic authority and advocate the} responsibility system of chief professor or chief engineer

Academic authority is a kind of influence based on personal academic accomplishment, achievement, experience, character of the teachers. The responsibility system of chief professor or chief engineer is adopted, and academic authority is given enough power, including the development planning and management of teaching and research, team building of teachers, organization and deployment between human resources and financial resources. The advantages of the academic authority are given full play to ensure the healthy development of the academic activities in colleges and universities. When teachers have a profound knowledge and a spirit of scientific inquiry, the academic authority can defeat the academic management. It is very necessary to put an end to use administrative orders to intervene and manage grassroots units, such as disciplines, research institutes, teaching and research section, research group. The waste of resources and decision-making mistakes caused by layman leading adept should be radically reduced, and it is no possible to let the administrative orders to suppress the enthusiasm and awareness of innovation of teachers.

\section{Strengthen team building of academic management in excellence engineers personnel training, establish and improve rules and regulations}

Improving the academic management agencies and building a high level of teaching academic management team of excellence engineers personnel training are the key to ensure the teaching quality of the innovative training model. University presidents should set up the survival awareness of the quality, strengthen the management of teaching quality, and pay attention to play an important combined role between school teaching working committee and the enterprise confederation. At the same time, a decisionmaking team with the overall capacity should be built, and this team can formulate teaching development planning. System is an important part of mechanism construction. The implementation of the functions for the academic organization, such as teaching working committee and the enterprise confederation, must have comprehensive rules and regulations as a guarantee, and these rules and regulations should be regarded as one of the most fundamental system of school. The academic power should enjoy equal importance position with administrative power, and has the highest authority in the academic field. The party's leading cadres at all levels should take the lead to comply with these rules and regulations, and anyone or anything can not override the system and can not have the privilege. Party and government leaders can not "undermine" the rules and regulations by virtue of the right in their hands.

\section{Strengthen the style of teaching and study, and academic atmosphere should fill the campus and enterprise}

The central work in the university is teaching and research, the fundamental task is to train senior professional and technical personnel, and teachers are the main body of schoolwork. The vinculum between teaching style and the style of study is "academic", the teaching style is the key, and its good or bad is subject to teaching academic management. Academic staffs are the main body of teaching academic management, and mobilizing the enthusiasm of the majority of professors, experts, scholars, corporate engineering and technical personnel involved in teaching management is fundamental to strengthen the teaching academic management in colleges and universities. The strong academic atmosphere emerges not only more new knowledge, new ideas and new perspectives, but also a good suggestion of innovative thinking and distinctive modern teaching academic management. All the staff and students should be mobilized to make concerted effort and coordinated operation to create a good teaching style and the style of study through their work. Under the influence of the 
academic atmosphere in the campus and enterprise, academic staffs have a sense of ownership in teaching academic management, and play a leading role.

\section{E. Understand the division between school and enterprise and establish correct cooperative relations}

College and university as an organization of the academic society, administrative management and academic management together constitute the backbone of the university management. Administrative management emphasizes on the responsibility of the directorate, namely subordinates obey their superiors, having the characteristics of strict management and efficient operation, and it focus on decision-making and implementation of administrative affairs. Academic management emphasizes on scientific proof and democratic management, and focus on the decision-making and management of academic field. Both run in clear terms of reference, and have the division and collaboration, but can not be substituted for each other. Only in this way can give full play to the advantages of both and can promote the healthy development of the university. As a industrial production base, enterprise provides a practical platform used to innovative design and display products to students, on the one hand provides the hardware conditions, on the other hand takes part in the school's academic management and student's learning management, providing the better practical advice and decision-making for schools.

\section{CONCLUSION}

Academic management in excellence engineers personnel training is not a general administrative management, based on the guiding ideology of running school and the goal of talent training, it requires to joint colleges and corporate to do a great quantity of education, teaching and research, and needs to take the bi-academic functions of teaching work and product innovative design. Therefore, strengthening the importance of academic management and deepening the reform of teaching management in excellence engineers personnel training have an important practical significance for improving the level of teaching management and promoting the implementation of innovative entrepreneurship education.

\section{ACKNOWLEDGMENT}

This research was sponsored by Teaching Reform of Higher Education Pilot Project of Heilongjiang Province (No. JG2201201110).

\section{REFERENCES}

[1] ZHAO Zhong-hua, LEI Jun. On the Academic Management of "Educational Administration in Colleges and Universities," vol. 18(1).Journal of Hunan Institute of Engineering(Social Science Edition), 2008, ,pp. 99-102.

[2] ZHANG Wei, LIU Hong-Shan. "Establish the Concept of Modern Education, Innovative Teaching Management," vol. 10. The Guide of Science \& Education, 2011, pp. 102-103.

[3] BIE Dun-rong, LIU Xiang-ju. "Higher Education Management and Assessment Research: Continuing Exploration on the Integration of Practical and Academic Value," vol. 31(9). Journal of Higher Education, 2010, pp.56-63.
[4] LI De-shan. "The Importance of Academic Management in Teaching Management of Institutions of Higher Learning," vol. 04. Journal of Hubei Institute for Nationalities, 2005, pp.157-159.

[5] SUN Shou-zeng. "Relationship of academic management and administration in universities from power view," vol. 13(1). Journal of Chang'an University(Social Science Edition), 2011, pp. 90-94.

[6] PENG Huan-cai. "Constructing a Teacher-oriented College Teaching Management," vol. 01. University Education Science, 2006, pp. 2628.

[7] Xiang Dong-chun, "A Positive Study of University Academic Personnel's Influence on Academic Affairs Management," vol. 20(5). Teacher Education Research, 2008, pp.25-32. 